\title{
The Growth Efficiency and Carcass Characteristics of Dorper Sheep Treated by Corn Inclusion as Energy into Palm Kernel Cake Based-Diet
}

\author{
O. A. Saeed ${ }^{\mathrm{a}, \mathrm{d}}$, A. Q. Sazilia , H. Akit ${ }^{\mathrm{a}}$, A. R. Alimon ${ }^{\mathrm{b}}$, M. Mazlan ${ }^{\mathrm{c}}$, \& A. A. Samsudin ${ }^{\mathrm{a} *}$ \\ ${ }^{a}$ Department of Animal Science, Faculty of Agriculture, Universiti Putra Malaysia, Selangor, 43400, Malaysia \\ ${ }^{b}$ Faculty of Animal Science, Universitas Gadjah Mada, Yogjakarta, Indonesia \\ 'Department of Veterinary Pathology and Microbiology, Faculty of Veterinary Medicine, Universiti Putra Malaysia, \\ Selangor, 43400, Malaysia \\ ${ }^{d}$ Department of Animal Science, Faculty of Agriculture, University of Anbar, Iraq \\ *Email of corresponding author: anjas@upm.edu.my \\ (Received 15-11-2017; Reviewed 29-11-2017; Accepted 24-01-2018)
}

\begin{abstract}
This study investigated the effect of energy as partial replacement of a diet based on palm kernel cake (PKC) on the growth performance, nutrient intake, digestibility, carcass quality, and economic cost of Dorper sheep. Twenty-seven Dorper rams (initial body weight $15 \pm 0.59 \mathrm{~kg}$ ) were kept in individual pens and divided randomly into dietary groups consisting of T1: basal diet $+0 \%$ corn (control), T2: basal diet $+5 \%$ corn, and T3: basal diet $+10 \%$ corn. Feed intake was recorded on a daily basis. On day 110, 4 lambs from each group were randomly chosen and transferred into metabolism crates to determine nutrient digestibility and completely randomized design was used. The results showed that high feed intake was in T3 while, the DM, CP, NDF, and ADF digestibility were decreased significantly with the increasing level of corn as an energy source. The carcass cuts were not affected by the dietary treatments. Significant differences were noted in the non-carcass parts (heart, lungs and trachea, defattted kidneys, liver, spleen, and kidney fat) with T3 having the highest value. The feeding cost was slightly increased when PKC was replaced by corn. In conclusion, inclusion of $10 \%$ corn as a source of energy in $65.3 \%$ PKC as fattening diets had effects on growth BW, ADG, and organs performance on Dorper lambs.
\end{abstract}

Keywords: carcass characteristics, corn, digestibility, Dorper sheep, palm kernel cake

\section{INTRODUCTION}

Cereal grains are the most costly feed among feedstuff and are necessary for the growth, reproduction, lactation, and other metabolic functions in livestock due to their high contents of energy, protein, and minerals among others components (Gimenez, 1994). These feed ingredients are in high demand by human which result in a competition with livestock. Therefore, this declines profitability of traditional livestock production systems and posed as is major challenge to farmers (Lupton et al., 2008), and it is, therefore, important to minimize the cost of feed by including cheaper protein sources without affecting the productivity of the animal. However, the quality of diet is mostly dependent on the ratio of energy to protein (Sayed, 2009). Lambs fed on energy: protein ratio of $10 \mathrm{MJ} / \mathrm{kg}$ DM: $12.4 \% \mathrm{CP}$ have the potential to have weight gains more rapidly $(125 \mathrm{~g} / \mathrm{d})$ (Poppi \& McLennan, 1995).

However, in developing countries, ruminants are mainly fed on crop residues which are deficient in crude protein $(\mathrm{CP})$ that are highly required by the animals (Sarwar et al., 2002). Indeed, protein is essential for growing ruminants but is costly (Dabiri \& Thonney, 2004). Malaysia produces huge amounts of PKC, which is an inexpensive source of high-quality feed for ruminants, having $16-20 \%$ protein content (Ribeiro et al., 2011). Palm kernel cake has been used as a feed ingredient for livestock both in ruminants and poultry (Alimon, 2004). Ruminants require a balanced diet which comprises of both energy and protein to meet up their requirements for both maintenance and production. Onwudike (1986) reported that PKC contains about 11.1 MJ of metabolizable energy (ME) $\mathrm{kg}^{-1}$. Due to the effect of copper toxicity in the PKC base diet, it's of paramount important to include an additional energy source thereby reducing the toxicity effect to the tolerable level with resultant improvement in growth and animal performance. Corn is a potential antioxidant that guards the body against harming by free radicals responsible for cellular damage and good source of energy that can improve the condition of the body (Kumar \& Jhariya, 2013). Inadequate energy level in sheep diet hindered animal performance more than any other nutritional deficiency. Therefore, this study was conducted to determine the effects of inclusion of corn as an energy source 
into PKC urea treated rice straw base-diet on the growth performance, nutrient intake, digestibility, carcass quality, and economic cost of Dorper sheep.

\section{MATERIALS AND METHODS}

\section{Animal Care}

The study was carried out in Serdang, Selangor, Malaysia $\left(3^{\circ} 2^{\prime} 0^{\prime \prime}\right.$ North, $101^{\circ} 43^{\prime} 0^{\prime \prime}$ East). The animal experimental procedures were conducted according to the Institutional Committee on Animal Use Ethics (Approval No. R064/2016). Twenty-seven Dorper lambs six-month-old with an average live weight of about $15 \pm$ $0.59 \mathrm{~kg}$ were randomly assigned and tested under three treatment modes comprising three levels of corn of $0 \%$, $5 \%$, and $10 \%$ included into PKC based-diet as a source of energy. The group receiving $0 \%$ of corn served as the control.

\section{Diet and Feeding}

Treatment 1 contained $75.3 \%$ PKC and $0 \%$ corn as a control diet, Treatment 2 contained 70.3\% PKC and 5\% corn, and Treatment 3 contained 10\% corn and 65.3\% PKC (Table 1). In the trial, dietary containing isonitrogen were used. The experimental treatments included equal portion offering of rice straw at $20 \%$ head/day on DM bases. Urea-treated rice straw (UTRS) was used as a basal diet and was prepared by pouring 3\% (wt/wt) urea mixed with $100 \mathrm{~kg}$ of water in $100 \mathrm{~kg}$ stacks of RS and then covered with a plastic sheet for a minimum of 15 days before being fed directly to the animals (Wanapat, 2009).

Animals were kept in individual pens $(1.5 \mathrm{~m} \mathrm{x} 1 \mathrm{~m})$ for 140 days with 15 days of adaptation. They were fed at random with the respective treatment diets, and water was available freely. At day 110, four animals from each treatment were randomly selected and moved to the metabolism crates for a digestibility trial. They were kept for 7 days involving 2 days for adaptation and 5 days for sample collection (feed and fecal). The chemical composition and ingredients of the concentrate are shown in Table 1.

\section{Analytical Procedures}

Feeds samples were randomly collected, and fecal samples were taken by rectal sampling from individual sheep, dried at $60^{\circ} \mathrm{C}$, and ground (1-mm screen using Cyclotech Mill, Teactor, Sweden) for proximate analysis of dry matter (DM), organic matter (OM), ether extract (EE), ash, crude fibre $(\mathrm{CF})$, crude perotein $(\mathrm{CP})$ content (AOAC, 1990), neutral detergent fiber (NDF), and acid detergent fiber ADF (Van Soest et al., 1991). Metabolizable energy (ME) was calculated using equation according to Menke \& Steingass (1988). Biological value and protein efficiency ratio were calculated to measure protein quality as a percent.
Biological value $=[(\mathrm{N}$ feed $-\mathrm{N}$ feces $-\mathrm{N}$ urine $) /(\mathrm{N}$ feed $-\mathrm{N}$ feces) $] \times 100$

Protein efficiency ratio $=$ Total of body weight gain $(\mathrm{g}) /$ Weight of protein consumption (g)

Nonfiber carbohydrates (NFC) was calculated to present a highly-digestible carbohydrate fraction of diets by following formula:

Nonfiber carbohydrates $=100 \%-(\% \mathrm{NDF}+\% \mathrm{CP}+\%$ fat $+\%$ ash).

However, economic cost of three diets were calculated. Fixed costs represent all costs other than the feeding costs. One US Dollar $=4.00$ Ringgit Malaysian.

where:

Total costs in US $\$$ = feeding + fixed costs.

Selling income in US\$ = total gain in weight $\times$ price of $\mathrm{kg}$ live weight.

Net income in US $\$$ = selling income - total costs.

Economic efficiency $=($ net income $/$ total costs $) \times 100$.

At the end of the trial, five animals from each group were selected for fasting for 12 hours. Prior to that, the fasting body weight (FBW) were recorded before being slaughtered according to the halal procedure as outlined in MS1500:2009 (Department of Standards Malaysia, 2009). After slaughtering and bleeding, the animals were skinned and dressed, and the hot carcass weight were recorded. Edible offal heart, liver, spleen, defatted kidneys, testicles, lungs, and trachea were separately weighed and recorded for each slaughtered animal. In addition, total inedible offal head, skin, and hooves weights were recorded. The hot carcass weight was recorded to evaluate the hot killing out percentage. During the first $24 \mathrm{~h}$ post slaughtered, the carcasses were stored in a ventilated cold room at $4^{\circ} \mathrm{C}$, after which their weights were measured to calculate cold killing out percentage and associated carcass losses. The carcasses were split along a vertical column into left and right halves by using a band saw. The left half was separated into six parts (neck, shoulder, loin, chest, leg, and rack) according to Marinova et al. (2001) with some modifications.

\section{Statistical Analysis}

Data obtained from each parameter were subjected to statistical analysis using the GLM (General Linear Model) procedure of Statistical Analysis Software (version 9.04). Analysis of variance and Duncan's multiple range tests were used to determine significant differences $(\mathrm{P}<0.01$ and 0.05$)$ among treatments. The differences among treatment groups were estimated using the following model:

$$
\mathrm{Y}_{i j}=\mu+\alpha_{i}+e_{i j^{\prime}}
$$

in which $Y_{i j}=$ dependent variable; $\mu$ = overall mean; $\alpha_{i}=$ The fixed effect is for inclusion level of corn ( 5 and $10 \%)$; and $e_{\mathrm{ij}}=$ experimental error assumed to be NID with $\left(0, \sigma^{2} e\right)$. 
RESULTS

\section{Nutrient Composition}

The proximate analysis of the three experimental rations is shown in Table 1 . The results indicate that diets containing corn were nearly similar in DM, CP, EE, and ash contents relative to the control ration. While, the proximate analysis of experimental rations showed that crude fibres were low in T2 and T3.

Table 1. Ingredients and chemical compositions of different inclusions of corn into palm kernel cake - urea-treated rice straw (DM basis)

\begin{tabular}{lccc}
\hline \multirow{2}{*}{\multicolumn{1}{c}{ Item }} & \multicolumn{3}{c}{ Levels of corn (\%) } \\
\cline { 2 - 4 } & $\mathrm{T} 1$ & $\mathrm{~T} 2$ & $\mathrm{~T} 3$ \\
\hline Urea-treated rice straw & 20 & 20 & 20 \\
PKC & 75.3 & 70.3 & 65.3 \\
Protected fat (Megalac) & 3 & 3 & 3 \\
Corn & 0 & 5 & 10 \\
$\mathrm{CaCO}_{3}$ & 1 & 1 & 1 \\
NaCl & 0.5 & 0.5 & 0.5 \\
Vitamin premix & 0.2 & 0.2 & 0.2 \\
Total & 100 & 100 & 100 \\
Chemical composition & & & \\
DM & 91.78 & 91.66 & 91.55 \\
Ash & 13.8 & 12.72 & 12.74 \\
OM & 86.19 & 87.27 & 87.26 \\
CP & 15.42 & 14.88 & 14.09 \\
EE & 5.3 & 5.1 & 4.33 \\
CF & 26.6 & 24.5 & 20.83 \\
NDF & 62.36 & 60.06 & 55.66 \\
ADF & 45.6 & 40.96 & 37.3 \\
ADL & 6.56 & 6.1 & 5.43 \\
Hemicellulose & 16.76 & 19.1 & 18.36 \\
Cellulose & 39.03 & 34.86 & 31.86 \\
NFE & 40.44 & 41.11 & 48.39 \\
ME MJ/Kg DM & 7.36 & 8.23 & 8.92 \\
\hline
\end{tabular}

Note: Vitamin premix; Vitamin A: 10,000,000 IU; Vitamin E: 70,000 IU; Vitamin D: 1,600,000 IU; DM: dry matter; OM: organic matter; CP: crude protein; EE: ether extract; $\mathrm{CF}$ : crude fiber; NDF: neutral detergent fiber; ADF: acid detergent fiber; ADL: acid detergent lignin; NFE: nitrogen free extract; ME: metabolizable energy.

\section{Growth Performance}

Body weight, FCR, and the nutrient value of the diet in animals fed different corn levels are shown in Table 2. Significant effect was observed in the final body weight among the treatments with $\mathrm{T} 3$ recorded with the highest body weight gain $(\mathrm{P}<0.05)$. The feed intake was different $(\mathrm{P}<0.05)$ in lambs fed diets containing different corn levels (Figure 1). Higher concentrate intakes were observed in the T3 but the lowest in the rice straw intake $(\mathrm{P}<0.05)$ in the same treatment. However, $\mathrm{T} 1$ and $\mathrm{T} 2$ were similar in concentrate and rice straw intake. The average daily feed intake was significantly affected by the level of corn with the lambs fed lower energy rations consuming more feed compared to those in the other treatment groups.

The PKC base-diet included with 5\% corn (T2) in the current study showed significant decreases $(\mathrm{P}<0.05)$ in the FCR compared with the control group. Moreover, biological values and protein efficiency ratios were significantly lower in lambs fed with 5\% corn than those fed with $0 \%$ corn and $10 \%$ corn. Nitrogen free carbohydrate showed no differences $(\mathrm{P}>0.05)$ among treatments groups. The growth rates of the Dorper lambs across the different treatments (Figure 2) increased as the level of corn supplementation was increased.

\section{Digestibility}

There were variations in apparent digestibility in the different treatments. Table 3 summarizes the apparent digestibility of feed DM, CP, NDF, and ADF digestibility which significantly decreased $(\mathrm{P}<0.01)$ when the lambs were fed with diets containing $10 \%$ corn as energy source compared to lambs fed on $0 \%$ of corn. With the increased in energy level, higher feed coefficient was observed. Likewise, feed coefficient was greater when energy levels increased.

\section{Carcass Characteristics}

Treatment groups had no significant $(\mathrm{P}>0.05)$ effect on hot carcass body weights (HCW) and the cold carcass body weights (CCW) (Table 4). Significant difference $(\mathrm{P}<0.05)$ was observed in the weight of head in lambs fed with $5 \%$ of corn (T2). However, no difference was

Table 2. Body weight, feed conversion ratio, and nutrients value of treatment diets fed to lambs

\begin{tabular}{|c|c|c|c|c|c|}
\hline \multirow{2}{*}{ Variables } & \multicolumn{5}{|c|}{ Treatments } \\
\hline & $\mathrm{T} 1$ & $\mathrm{~T} 2$ & T3 & SEM & P-value \\
\hline Initial live weight (kg) & 15.53 & 15.37 & 15.6 & 0.36 & NS \\
\hline Final live weight (kg) & $25.20^{\mathrm{b}}$ & $26.22^{\mathrm{ab}}$ & $27.12^{\mathrm{a}}$ & 0.3 & * \\
\hline Average weight gain $(\mathrm{g} / \mathrm{d})$ & $81.23^{\mathrm{b}}$ & $91.17^{\mathrm{ab}}$ & $98.22^{a}$ & 3.17 & * \\
\hline FCR (g:g) & $14.83^{\mathrm{ab}}$ & $13.47^{b}$ & $18.35^{\mathrm{a}}$ & 0.93 & * \\
\hline Biological value (\%) & $34.10^{\mathrm{ab}}$ & $30.63^{b}$ & $37.55^{\mathrm{a}}$ & 1.03 & ** \\
\hline Protein efficiency ratio (\%) & $0.80^{c}$ & $0.93^{\mathrm{b}}$ & $1.12^{\mathrm{a}}$ & 0.02 & $* * *$ \\
\hline Nonfiber carbohydrates (\%) & 14.26 & 14.5 & 19.2 & 1.23 & NS \\
\hline
\end{tabular}

Note: T1: (75.3\% PKC + 0\% corn), T2: (70.3\% PKC + 5\% corn), T3: (65.3\% PKC + 10\% corn).

NS not significant statistically $(\mathrm{P}>0.05)$. ${ }^{\mathrm{a}, \mathrm{b}, \mathrm{c}}$ Means in the same row with different superscripts differ significantly at ${ }^{*} \mathrm{P}<0.05,{ }^{* *} \mathrm{P}<0.01,{ }^{* * *} \mathrm{P}<0.001$. 


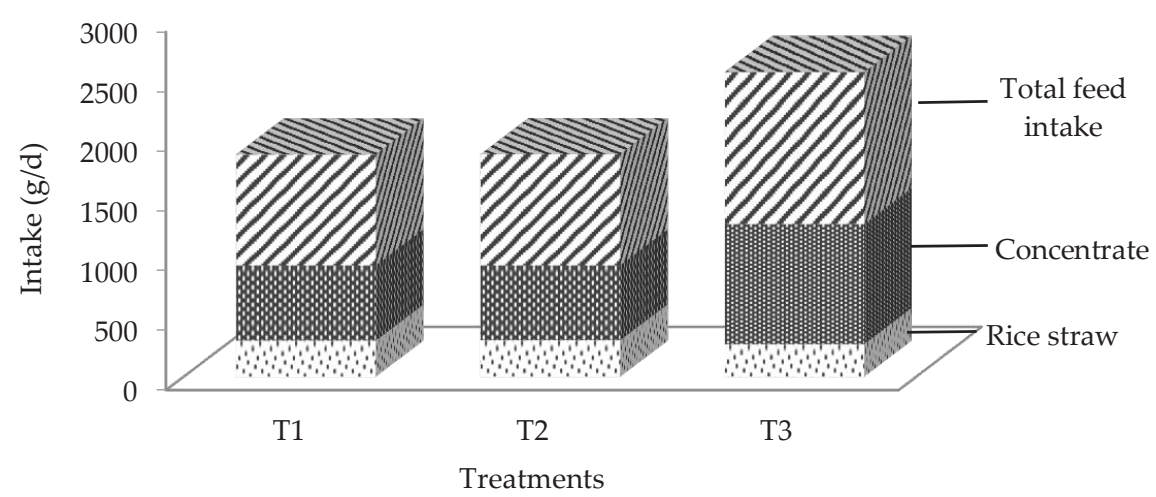

Figure 1. Proportion of feed consumed from total DMI $(\mathrm{g} / \mathrm{d})$ for each treatment. T1: $(75.3 \% \mathrm{PKC}+0 \%$ corn), T2: $(70.3 \%$ PKC $+5 \%$ corn), T3: (65.3\% PKC + 10\% corn).

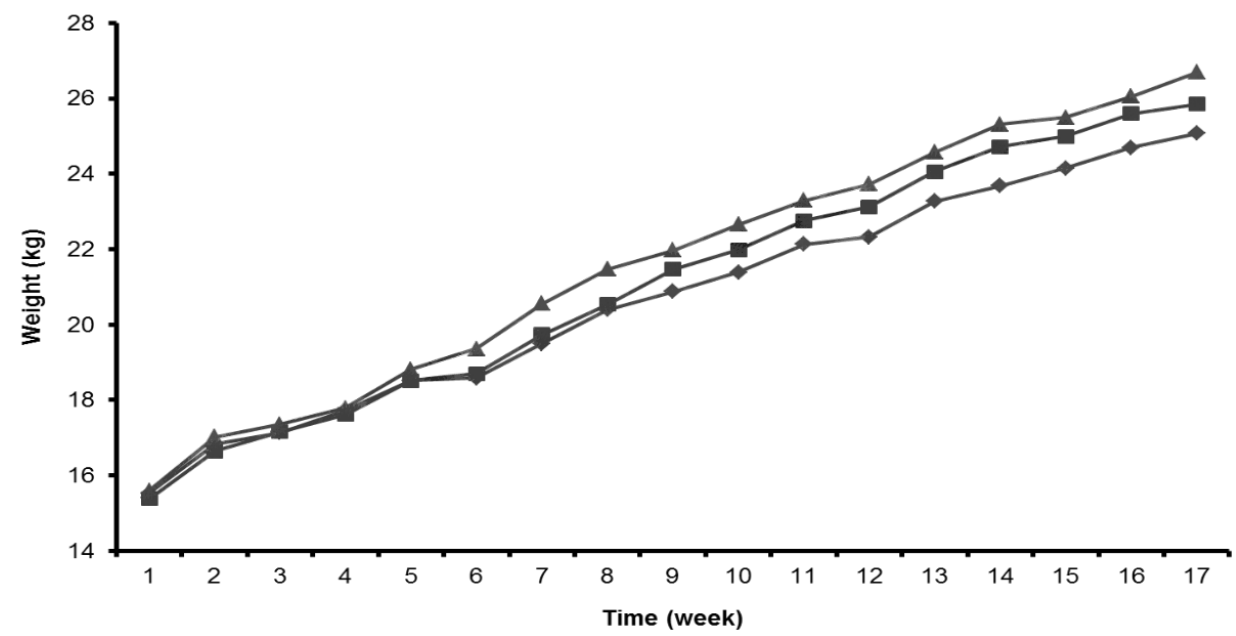

Figure 2. Growth rate of indigenous lambs fed different levels of palm kernel cake. T1 (-•-): (75.3\% PKC + 0\% corn), T2 (-m-): (70.3\% PKC + 5\% corn), T3 (- $\mathbf{\Delta - ) : ~ ( 6 5 . 3 \% ~ P K C ~ + ~ 1 0 \% ~ c o r n ) . ~}$

Table 3. Nutrient digestibility of sheep fed different dietary treatments

\begin{tabular}{|c|c|c|c|c|c|}
\hline \multirow{2}{*}{ Variables (\%) } & \multicolumn{5}{|c|}{ Treatments } \\
\hline & $\mathrm{T} 1$ & $\mathrm{~T} 2$ & T3 & SEM & P-value \\
\hline Feed coefficient & $42.30^{b}$ & $41.83^{b}$ & $48.64^{\mathrm{a}}$ & 0.92 & ** \\
\hline DM Digestibility & $46.22^{\mathrm{a}}$ & $45.09^{a}$ & $41.76^{\mathrm{b}}$ & 0.67 & ** \\
\hline OM Digestibility & $48.53^{b}$ & $50.78^{a}$ & $46.27^{c}$ & 0.39 & * \\
\hline CP Digestibility & $67.15^{\mathrm{a}}$ & $65.53^{a}$ & $61.02^{\mathrm{b}}$ & 0.94 & $* *$ \\
\hline NDF Digestibility & $40.67^{a}$ & $38.68^{b}$ & $27.82^{c}$ & 1.22 & ** \\
\hline ADF Digestibility & $29.66^{a}$ & $23.86^{b}$ & $9.22^{c}$ & 1.84 & * \\
\hline
\end{tabular}

Note: T1: (75.3\% PKC + 0\% corn), T2: (70.3\% PKC + 5\% corn), T3: (65.3\% PKC + 10\% corn).

NS not significant statistically ( $P>0.05)$. ${ }^{a, b, c}$ Means in the same row with different superscripts differ significantly at ${ }^{*} \mathrm{P}<0.05,{ }^{* *} \mathrm{P}<0.01$.

noted in the weight of skin and hooves among the treatment groups. The results of the carcass cuts of the sheep are shown in Table 5 . The different in the treatments diets did not influence shoulder, loin, chest, leg, and rib weights $(\mathrm{P}>0.05)$. Animals fed T2 and T3 diets had greater $(\mathrm{P}<0.05)$ neck weight than $\mathrm{T} 1$. Moreover, lambs fed on T3 diet had greater heart, liver, lungs, trachea, kidney fat $(\mathrm{P}<0.01)$, and spleen $(\mathrm{P}<0.05)$ weights than lambs offered the T1 diet (Table 6).

\section{Cost Implication}

The cost of feed $\mathrm{kg} /$ head was higher in lambs fed with T3 rations (US\$50.47) compared to those fed T2 
Table 4. The effects of feeding different dietary treatments on slaughter traits of sheep carcass

\begin{tabular}{lccccc}
\hline \multirow{2}{*}{ Variables } & \multicolumn{4}{c}{ Treatments } \\
\cline { 2 - 6 } & T1 & T2 & T3 & SEM & P-value \\
\hline Slaughter weight $(\mathrm{kg})$ & 26.73 & 27.33 & 28.93 & 0.9 & NS \\
Hot carcass weight $(\mathrm{kg})$ & 10.15 & 10.7 & 11.46 & 0.33 & NS \\
Cold carcass weight $(\mathrm{kg})$ & 9.66 & 10.21 & 11.06 & 0.36 & NS \\
Dressing HCW & 38 & 39.25 & 39.69 & 0.58 & NS \\
Dressing CCW & 36.13 & 37.51 & 38.3 & 0.74 & NS \\
Head $(\mathrm{kg})$ & $1.85^{\mathrm{a}}$ & $1.73^{\mathrm{b}}$ & $1.86^{\mathrm{a}}$ & 0.02 & $*$ \\
Hooves $(\mathrm{g})$ & 600 & 706.67 & 733.33 & 30.18 & NS \\
Skin $(\mathrm{kg})$ & 2.46 & 2.75 & 2.63 & 0.07 & NS \\
\hline
\end{tabular}

Note: T1: (75.3\% PKC + 0\% corn), T2: (70.3\% PKC + 5\% corn), T3: (65.3\% PKC + 10\% corn)

NS not significant statistically $(\mathrm{P}>0.05)$. ${ }^{\mathrm{a}, \mathrm{b}, \mathrm{c}}$ Means in the same row with different superscripts differ significantly at $\mathrm{P}<0.05$.

Table 5. The effects of different levels of corn on cuts of sheep carcass

\begin{tabular}{lccccc}
\hline \multirow{2}{*}{ Variables (g) } & \multicolumn{3}{c}{ Treatments } & SEM & P-value \\
\cline { 2 - 6 } & T1 & T2 & T3 & 20.05 & $*$ \\
Neck & $260.00^{\mathrm{b}}$ & $345.00^{\mathrm{a}}$ & $363.33^{\mathrm{a}}$ & 76.2 & $\mathrm{NS}$ \\
Shoulder & 696.7 & 925 & 966.7 & 31.21 & $\mathrm{NS}$ \\
Loin & 470 & 490 & 1396.7 & 49.37 & $\mathrm{NS}$ \\
Chest & 1240 & 1230 & 1990 & 64.5 & NS \\
Leg & 1735 & 1866.7 & 330 & 14.37 & NS \\
Ribs & 280 & 320 & & \\
\hline
\end{tabular}

Note: T1: (75.3\% PKC + 0\% corn), T2: (70.3\% PKC + 5\% corn), T3: (65.3\% PKC + 10\% corn).

NS not significant statistically $(\mathrm{P}>0.05)$. ${ }^{\mathrm{a}, \mathrm{b}, \mathrm{c}}$ Means in the same row with different superscripts differ significantly at $\mathrm{P}<0.05$.

Table 6. The effects of different levels of corn on parts of noncarcass

\begin{tabular}{|c|c|c|c|c|c|}
\hline \multirow{2}{*}{ Variables (g) } & \multicolumn{5}{|c|}{ Treatments } \\
\hline & $\mathrm{T} 1$ & $\mathrm{~T} 2$ & T3 & SEM & P-value \\
\hline Heart & $123.00^{c}$ & $136.67^{b}$ & $159.00^{a}$ & 5.25 & ** \\
\hline Lungs and trachea & $305.33^{c}$ & $328.33^{\mathrm{b}}$ & $350.33^{a}$ & 6.95 & $* *$ \\
\hline Defat kidneys & $68.66^{a}$ & $69.33^{a}$ & $72.00^{\mathrm{a}}$ & 1.1 & NS \\
\hline Liver & $313.67^{c}$ & $345.33^{\mathrm{b}}$ & $381.67^{a}$ & 9.87 & $* * *$ \\
\hline Spleen & $27.66^{\mathrm{b}}$ & $21.66^{\mathrm{a}}$ & $32.00^{\mathrm{a}}$ & 0.96 & * \\
\hline Testicles & $300.00^{a}$ & $197.00^{\mathrm{b}}$ & $265.00^{\mathrm{ab}}$ & 18.41 & * \\
\hline Kidneys fat & $112.00^{\mathrm{b}}$ & $106.00^{\mathrm{b}}$ & $214.33^{\mathrm{a}}$ & 17.6 & $* * *$ \\
\hline
\end{tabular}

Note: T1: (75.3\% PKC + 0\% corn), T2: (70.3\% PKC + 5\% corn), T3: (65.3\% PKC + 10\% corn).

NS not significant statistically $(\mathrm{P}>0.05)$. ${ }^{\mathrm{a}, \mathrm{b}, \mathrm{c}}$ Means in the same row with different superscripts differ significantly at ${ }^{*} \mathrm{P}<0.05,{ }^{* *} \mathrm{P}<0.01,{ }^{* * *} \mathrm{P}<0.001$.

and T1 diets. Net income at US\$36.46 was lowest in T1 compared with T2 and T3 rations (Table 7) which had an average of US\$47.45 and US\$53.56, respectively. The lambs fed T3 rations showed $88.57 \%$ higher economic efficiency and $113.93 \%$ higher selling income than those fed with T1 rations.

\section{DISCUSSION}

\section{Growth Performance}

Highest intake of concentrate based diet in addition to lower of urea-treated rice straw was observed in animal fed T3 diet. However, similar intake of rice straw was observed when fed T1 and T2. The average daily feed intake was significantly affected by the level of corn with the lambs fed higher energy rations consuming more feed compared to those in the control groups (Figure 1). This result is in agreement with Russell et al. (2011) which reported that DM intake increased significantly $(\mathrm{P}<0.05)$ in ruminants fed diet containing $70 \%$ corn (DM basis). Regardless of this result, rumen fermentation activities could be enhanced by increasing the levels of energy with resultant increased in microbial protein synthesis and the amount of available protein (Sayed, 2009). Rahman et al. (2013) reported high FCR on goat fed with rations containing high PKC which agree with the present study in which FCR was higher 
Table 7. Economic efficiency of feeding palm kernel cake with different levels of corn to Dorper lambs

\begin{tabular}{lccc}
\hline \multirow{2}{*}{ Economic item } & \multicolumn{3}{c}{ Treatments } \\
\cline { 2 - 4 } & $\mathrm{T} 1$ & $\mathrm{~T} 2$ & $\mathrm{~T} 3$ \\
\hline Total gain in weight (kg) & 9.67 & 10.85 & 11.52 \\
Total feeding costs/head (US\$) & 49 & 49.86 & 50.47 \\
Fixed costs (US\$) & 10 & 10 & 10 \\
Total costs (US\$) & 59 & 59.86 & 60.47 \\
Price of kg live BW (US\$) & 9.89 & 9.89 & 9.89 \\
Selling income (US\$) & 95.64 & 107.31 & 113.93 \\
Net income (US\$) & 36.46 & 47.45 & 53.56 \\
Economic efficiency (\%) & 61.8 & 79.27 & 88.57 \\
\hline
\end{tabular}

Note: T1: (75.3\% PKC + 0\% corn), T2: (70.3\% PKC + 5\% corn), T3: (65.3\% PKC $+10 \%$ corn).

in sheep fed a diet containing 10\% corn and $65.3 \%$ PKC. The high FCR in this treatment (T3) may be related to the highest feed intake as a reflection of a more palatabel diet compared to T1. Sheep fed with $10 \%$ corn had higher $(\mathrm{P}<0.05)$ final body weight and ADG than those fed with control diet (Table 2). This finding conflicted with previous studies conducted by Zahari \& Alimon (2005) and Tipu et al. (2014) reporting that ruminants consuming low levels of PKC had lower daily weight gain $(\mathrm{P}<0.05)$ although sheep consuming moderate level of PKC did not have effect on daily weight gain. This finding conflicted with the present study where sheep with the highest ADG had lower level of PKC (T2 and T3) compared to control group fed on high level of PKC. The reason could be due to inclusion of corn in the diet that can promote a greater weight gain. The result showed that the indicators of protein quality gave more precision than the weight gains alone (Carpenter et al., 1972). Those results coincide with the present study where the diet with $10 \%$ corn resulted in a better protein quality with higher weight gains indicating that the precision of the result is similar with the biological value and protein efficiency ratio.

Figure 2 shows that the lambs with the highest and lowest growing parameters, i.e., T3 and T1, respectively, used the PKC as based diet during the experiment. Previous studies showed that ruminants fed PKC as based diets had improved growth performance (Jelan et al., 1991). The lambs fed on certain level of corn are tended to have higher growth rate when PKC were combined with corn, but the growth rate will be dropped when the labs fed PKC alone. This result was due to the higher requirements for maintenance energy.

\section{Digestibility}

The lambs fed PKC diet at $65.3 \%+$ corn at $10 \%$ (T3) had the highest feed consumption which might be attributed to the decrease in CF and NDF as a result of additional high energy content in this treatment group. This low CF and NDF resulted in an improved palatability which subsequently led to high feed intake with profound effect on nutrient digestibility with resultant improvement on the ADG. With high feed intake, the rate of passage through the gastro-intestinal tract increases (Kitessa et al., 1999). NDF is the primary chemical constraint of feeds that determines their rates of digestion. This constituent is a measure of cell wall content and rumen fill. In this case, only when the NDF is digested that its effect on rumen fills can be eliminated (Allen, 1996).

\section{Carcass Characteristics}

Carcass characteristics (Table 4) were considered normal $(\mathrm{P}>0.05)$ for Dorper sheep and are in agreement with result reported by Souza et al. (2013) who reported an increased in animal performance and carcass characteristics in the same breed of sheep. The slaughter weight of Dorper sheep was around $27.66 \mathrm{~kg}$ which was similar to previous studies (Terblanche et al., 1973). The high slaughter weight found in the present study could be due to an early age of fat gain. The levels of energy across different treatment groups were optimal for lamb growth and health requirements in the present study. Similar dressing percentages were observed among treatments group but lower than those reported by Notter et al. (2004) and Ocak et al. (2016) in the same breed. Van Niekerk \& Steenkamp (1995) stated that dressing percentage increased with slaughter age of lambs from approximately $40 \%$ when slaughtered at 25 $\mathrm{kg}$ live weight to approximately $50 \%$ when slaughtered at a live weight of $40 \mathrm{~kg}$. Inline with the present study, Souza et al. (2013) reported that Dorper lambs had higher pre-slaughter weight and better carcass grade but with less dressing percentage and fat levels in Dorper sheep. The difference in the body weight observed in this study could be due to the level of energy inclusion of finishing diets fed to the lambs. This emphases the importance of subcutaneous fat thickness in protecting the carcasses during the cooling process.

The reduction of the carcass weight (shoulder, loin, chest, legs, and ribs) was explained by the results stated earlier for ADG, nutrient intakes, and digestibility. This finding is in agreement with previous study conducted by Obeidat et al. (2008), while the numeric gain in carcass cuts (shoulder, loin, chest, legs, and ribs) may be due to the rate and efficiency of the gain which occurs when the animals consume the highest percentage of a given diet which is in agreement with the findings of Fluharty \& McClure (1997). Davies (1989) also pointed out that changes in body proportions and composition are brought about by differential growth gradients existing between the different parts and tissues of the body. Notter et al. (2004) had reported that differences were not observed in the percentage of carcass weight in the leg or loin of Dorper sheep. However, there was no difference for cut yield as a function of the levels of inclusion of PKC in our study except neck weight. The results found by dos Santos et al. (2017) showed there was a reduction in the commercial cut weight, except for the neck weight for animals that were fed on $7 \%$ of PKC which provided the greatest neck weight and the lowest weight was observed those fed with $30 \%$ of PKC. The utilization of five concentrations of crude glycerin $(0,3$, 6,9 and $12 \%$ of DM) as a substitute of ground corn by Lage et al. (2014) justified the well-balanced distribution 
of muscle and fat in the body of animals since commercial cuts represent the tissue distribution in different regions of the carcass.

The significance of these findings lie in the fact that reducing of visceral organ mass should reduce the energy requirements of the animal and our results was in agreement with the findings of Burrin et al. (1992) and Fluharty \& McClure (1997). Burrin et al. (1992) reported that the level of feed intake affected visceral organ mass without changing the DNA mass of the organ due to changes in cellular hypertrophy rather than changes in cell numbers. Kirton et al. (1972) reported that the live weight and nutritional status of animals could affect the production efficiency of carcass offal. This is while noting that the inclusion of PKC in the diet caused a certain degree of feed restriction thereby lowering the weight of the primary metabolic organs such as the liver, heart, and small and large intestines (dos Santos et al., 2017).

\section{Cost Implication}

The parameters employed in economic evaluation of the three diets are summarized in Table 7 . The energy supplemented in diets were similar in terms of feeding cost during the whole fattening period of the lambs ranging from about US\$49 for T1, US\$49.86 for T2, and US\$50 for T3, respectively. The diet included with 10\% corn (T3) recorded the highest in economic efficiency of about $(88.57 \%)$ in comparison with the control diet while that inclusion level at 5\% corn was lower in economic efficiency by about $79.29 \%$ when compared with the control diet. Research has shown that supplementing corn into PKC diet improves growth rate and feed efficiency when fed to lambs compared to PKC alone. Sheep producers aim to decrease the feed costs by choosing suitable breeds that efficiently convert feed to meat. The carcass trait of the Dorper breed was a major positive attribute, but minor benefits gained in carcass cuts with the inclusion of corn does not justify the substantial additional cost of production.

\section{CONCLUSION}

Inclusion of $10 \%$ corn as energy source in the diets of fattening Dorper lambs has improved their growth performance, nutrient intake, and weight of organs. However, more research is needed to determine the critical inclusion level of energy into PKC diets in finishing lamb rations that could affect performance and carcass characteristics of the lamb.

\section{ACKNOWLEDGEMENT}

The authors extend their appreciations to Universiti Putra Malaysia (UPM) for funding this work and the Higher Education Ministry of Iraq and Al Anbar University for their support.

\section{REFERENCES}

Alimon, A. 2004. The nutritive value of palm kernel cake for animal feed. Palm Oil Dev. 40: 12-14.
Allen, M.S. 1996. Physical constraints on voluntary intake of forages by ruminants. J. Anim. Sci. 74: 3063-3075. https:// doi.org/10.2527/1996.74123063x

AOAC. 1990. Association of Official Analytical Chemistry. Official methods of analysis. AOAC International, Arlington, VA.

Burrin, D., R. Britton, C. Ferrell, \& M. Bauer. 1992. Level of nutrition and visceral organ protein synthetic capacity and nucleic acid content in sheep. J. Anim. Sci. 70: 1137-1145. https://doi.org/10.2527/1992.7041137x

Carpenter, K., I. McDonald, \& W. Miller. 1972. Protein quality of feeding-stuffs: $5 .^{*}$ Collaborative studies on the biological assay of available methionine using chicks. Br. J. Nutr. 27: 7-17. https://doi.org/10.1079/BJN19720064

Dabiri, N. \& M. Thonney. 2004. Source and level of supplemental protein for growing lambs. J. Anim. Sci. 82: 3237-3244. https://doi.org/10.2527/2004.82113237x

Davies, A. 1989. Growth changes in the meat carcass. Occasional Publication. 11: 61-72.

Department of Standards Malaysia. 2009. MS1500: 2009 (1st revision) Halal foodproduction, preparation, handling and storage-general guideline pp. 1-13.

dos Santos, R.d.C., D.I. Gomes, K.S. Alves, R. Mezzomo, L.R.S. Oliveira, D.O. Cutrim, S.B.M. Sacramento, E. de Moura Lima, \& F.F.R. de Carvalho. 2017. Carcass characteristics and meat quality of lambs that are fed diets with palm kernel cake. Asian-Australas. J. Anim. Sci. 30: 865. https://doi. org/10.5713/ajas.16.0424

Fluharty, F. \& K. McClure. 1997. Effects of dietary energy intake and protein concentration on performance and visceral organ mass in lambs. J. Anim. Sci. 75: 604-610. https:// doi.org/10.2527/1997.753604x

Gimenez, J.D.M. 1994. Nutrient requirements of sheep and goats. Circular ANR (USA).

Jelan, Z., Y. Ishak \& T. Yaakub. 1991. Feedlotting of cattle on palm kernel cake in small holder farming system. Proc. 14th Ann. Conf. Malaysian Soc. Anim. Prod, pp. 99-102.

Kirton, A., P. Fourie, \& K. Jury. 1972. Growth and development of sheep: III. Growth of the carcass and non-carcass components of the Southdown and Romney and their cross and some relationships with composition. N. Z. J. Agric. Res. 15: 214-227. https://doi.org/10.1080/00288233.1972.10 421249

Kitessa, S., G. Irish, \& P. Flinn. 1999. Comparison of methods used to predict the in vivo digestibility of feeds in ruminants. Aust. J. Agric. Res. 50: 825-842. https://doi. org/10.1071/AR98169

Kumar, D. \& A.N. Jhariya. 2013. Nutritional, medicinal and economical importance of corn: A mini review. Res. J. Pharm. Sci. 2: 7-8.

Lage, J., P. Paulino, L. Pereira, M. Duarte, S. Valadares Filho, A. Oliveira, N. Souza, \& J. Lima. 2014. Carcass characteristics of feedlot lambs fed crude glycerin contaminated with high concentrations of crude fat. Meat Sci. 96: 108113. https://doi.org/10.1016/j.meatsci.2013.06.020

Lupton, C., J. Huston, J. Hruska, B. Craddock, F. Pfeiffer, \& W. Polk. 2008. Comparison of three systems for concurrent production of high quality mohair and meat from Angora male kids. Small Rumin. Res. 74: 64-71. https://doi. org/10.1016/j.smallrumres.2007.03.008

Marinova, P., V. Banskalieva, S. Alexandrov, V. Tzvetkova, \& H. Stanchev. 2001. Carcass composition and meat quality of kids fed sunflower oil supplemented diet. Small Rumin. Res. 42: 217-225. https://doi.org/10.1016/ S0921-4488(01)00245-0

Menke, K.H., \& H. Steingass. 1988. Estimation of the energetic feed value obtained from chemical analysis and in vitro gas production using rumen fluid. Anim Res Dev. 28: 7-55.

Notter, D., S. Greiner, \& M. Wahlberg. 2004. Growth and 
carcass characteristics of lambs sired by Dorper and Dorset rams. J. Anim. Sci. 82: 1323-1328. https://doi. org/10.2527/2004.8251323x

Obeidat, B.S., A.Y. Abdullah, M.S. Awawdeh, R.T. Kridli, H.H. Titi, \& R.I. Qudsieh. 2008. Effect of methionine supplementation on performance and carcass characteristics of Awassi ram lambs fed finishing diets. Asian-Australas. J. Anim. Sci. 21: 831. https://doi.org/10.5713/ajas.2008.70536

Ocak, S., S. Ogun, \& O. Yilmaz. 2016. Dorper sheep utilizing feed resources efficiently: a Mediterranean case study. Rev. Bras. Zootec. 45: 489-498. https://doi.org/10.1590/ S1806-92902016000800010

Onwudike, O. 1986. Palm kernel meal as a feed for poultry. 1. Composition of palm kernel meal and availability of its amino acids to chicks. Anim. Feed Sci. Technol. 16: 179-186. https://doi.org/10.1016/0377-8401(86)90108-2

Poppi, D.P. \& S. McLennan. 1995. Protein and energy utilization by ruminants at pasture. J. Anim. Sci. 73: 278-290. https://doi.org/10.2527/1995.731278x

Rahman, M.M., R.B. Abdullah, W.K.W. Embong, T. Nakagawa, \& R. Akashi. 2013. Effect of palm kernel cake as protein source in a concentrate diet on intake, digestibility and live weight gain of goats fed Napier grass. Trop. Anim. Health. Prod. 45: 873-878. https://doi.org/10.1007/ s11250-012-0300-4

Ribeiro, R.D.X., R.L. Oliveira, F.M. Macome, A.R. Bagaldo, M.C.A.d. Silva, C.V.D.M. Ribeiro, G.G.P.d. Carvalho, \& D.P.D. Lanna. 2011. Meat quality of lambs fed on palm kernel meal, a by-product of biodiesel production. AsianAust. J. Anim. Sci. 24: 1399 - 1406.

Russell, J.R., D.D. Loy, J. Anderson, \& M. Cecava. 2011. Potential of chemically treated corn stover and modified distiller grains as a partial replacement for corn grain in feedlot diets. Anim. Indust. Rep. 657: 10.

Sarwar, M., M.A. Khan, \& Z. Iqbal. 2002. Status paper feed resources for livestock in Pakistan. Int. J. Agric. Biol. 4: 186-192.
Sayed, A.-B.N. 2009. Effect of different dietary energy levels on the performance and nutrient digestibility of lambs. Vet. World. 2: 418-420.

Souza, D., A. Selaive-Villarroel, E. Pereira, J. Osório, \& A. Teixeira. 2013. Growth performance, feed efficiency and carcass characteristics of lambs produced from Dorper sheep crossed with Santa Inês or Brazilian Somali sheep. Small Rumin. Res. 114: 51-55. https://doi.org/10.1016/j. smallrumres.2013.06.006

Terblanche, I.L., A.M. Mulder, L.P. Nel, \& R. J.W. 1973. Inuence of crop feeding and supplementary feeding on weight gain and carcass grading of Dorper lambs (in Afrikaans), Agroanimalia, pp. 1-6.

Tipu, M., F. Ahmad, A. Khalique, M. Haque, R. Mirza, \& U. Tayyab. 2014. Replacement of cotton seed cake with palm kernel cake in growing Nili-ravi buffalo male calves. J. Anim. Plant. Sci. 24: 24-27.

Van Niekerk, W. \& K. Steenkamp. 1995. Comparison of three types of Dorper lambs (wool, hair and intermediate type) with regard to growth, feed and water intake, protein and fat metabolism. Dorper Sheep Breeders' Society of South Africa, Middelburg, South Africa.

Van Soest, P.v., J. Robertson, \& B. Lewis. 1991. Methods for dietary fiber, neutral detergent fiber, and nonstarch polysaccharides in relation to animal nutrition. J. Dairy. Sci. 74: 3583-3597. https://doi.org/10.3168/jds. S0022-0302(91)78551-2

Wanapat, M. 2009. Potential uses of local feed resources for ruminants. Trop. Anim. Health. Prod. 41: 1035. https://doi. org/10.1007/s11250-008-9270-y

Zahari, M.W. \& A. Alimon. 2005. Use of palm kernel cake and oil palm by-products in compound feed. Palm Oil Dev. 40: 5-8. 